\title{
IMPACTS OF NONNATIVE PLANT SPECIES ON PRODUCTION AND DIVERSITY IN THE FRONT RANGE OF COLORADO
}

\author{
Kerry M. Byrne ${ }^{1}$, William K. Lauenroth² ${ }^{\text {, and Lindsay McManus }}{ }^{3}$
}

\begin{abstract}
Nonnative plant species are considered one of the greatest threats to biodiversity, yet we still are unable to predict how production and diversity of a community will change once a species has invaded. Ponderosa pine woodlands in the Front Range of Colorado are ideal for studying the impacts of nonnative plants on production and species richness. We selected 5 sites along the northern Front Range with varying proportions of nonnative and native species and compared understory production and species richness along the gradient of nonnative species dominance. Total species production was positively and significantly related to total species richness, and total species production increased significantly with increasing nonnative species richness. There was a negative relationship between native and nonnative species production, and there was no relationship between nonnative species richness and native species richness. This study demonstrates the complex nature of species richness and productivity relationships and should serve as a starting point for future research in which a variety of other variables are considered.
\end{abstract}

Key words: species richness, productivity, nonnative species, ponderosa pine woodlands, Front Range, Colorado.

The effects of nonnative species invasions are one of the major threats to biodiversity, second only to direct habitat destruction (Vitousek et al. 1997, Wilcove et al. 1998, Mack et al. 2000). The current and potential ecological and economic impacts of nonnative species are large, making biotic invasions a topic of concern for both land managers and ecologists. However, answers to simple questions, such as what makes a community invasible, and once invaded, how net primary production and species richness change, still elude ecologists (Ehrenfeld 2003). Ecologists continue to ask such questions regarding nonnative species invasions, yet studies have shown conflicting results.

The ecosystems of the Front Range of Colorado are ideal for studying the impacts of nonnative species on primary production and species richness. Ponderosa pine forests and woodlands of the central and southwestern U.S. have been substantially altered over the past 150 years by humans (Covington and Moore 1994, Swetnam et al. 1999, Veblen et al. 2000, Allen et al. 2002). Livestock grazing, fire suppression, logging, and recent human settlement in ponderosa pine communities in the Front Range have provided frequent disturbance and strong propagule pressure for nonnative species introductions. These activities have caused large changes in both the understory and overstory vegetation. Understory changes are especially visible, where a variety of exotic grasses and forbs have invaded, including Bromus inermis (smooth brome), Bromus tectorum (cheatgrass), and Linaria dalmatica (Dalmation toadflax).

We conducted research in ponderosa pine woodlands of the Colorado Front Range to answer the following questions: How has the invasion by nonnative plant species changed understory aboveground net primary production (ANPP)?; And how has nonnative plant invasion influenced native species richness? Our predictions were as follows: Plots with the greatest nonnative plant production will have the greatest ANPP. This prediction is based on Ehrenfeld's (2003) review of published literature, in which the majority of studies found that areas with increased nonnative plant production had the greatest biomass. Also, plots with the greatest number of native species will also have the highest number of nonnative species. This prediction is based on the Fridley et al. (2007) review of invasion literature, in which the authors found that, generally, rich native ecosystems are also a hotspot of invasions.

As exurban development along the Front Range continues, it will be important to understand the relationship between nonnative

\footnotetext{
${ }^{1}$ Graduate Degree Program in Ecology, Colorado State University, Fort Collins, CO 80523. E-mail: kmbyrne@rams.colostate.edu

${ }^{2}$ Department of Botany, University of Wyoming, Laramie, WY 82071.

${ }^{3}$ Department of Statistics, Colorado State University, Fort Collins, CO 80523.
} 
TABLE 1. Study site names and information on site locations, elevations, slopes, annual precipitation (2007), and precipitation during the study period (June-August 2007).

\begin{tabular}{lccccc}
\hline Site name & Location & $\begin{array}{c}\text { Elevation } \\
(\mathrm{m})\end{array}$ & $\begin{array}{c}\text { Slope } \\
(\%)\end{array}$ & $\begin{array}{c}\text { Annual ppt. } \\
(\mathrm{mm})\end{array}$ & $\begin{array}{c}\text { Jun-Aug ppt. } \\
(\mathrm{mm})\end{array}$ \\
\hline $\begin{array}{l}\text { (1) Hewlett Gulch trail, } \\
\quad \text { Roosevelt National Forest }\end{array}$ & $40.70^{\circ},-105.30^{\circ}$ & 1841 & 9.5 & 461 & 145 \\
$\begin{array}{l}\text { (2) Lefthand Canyon OHV Area, } \\
\quad \text { Roosevelt National Forest }\end{array}$ & $40.10^{\circ},-105.32^{\circ}$ & 1953 & 14 & 485 & 104 \\
$\begin{array}{l}\text { (3) Golden Gate Canyon State Park } \\
\text { (4) St. Vrain Canyon, }\end{array}$ & $39.85^{\circ},-105.35^{\circ}$ & 2441 & 5 & 552 & 141 \\
$\quad$ Roosevelt National Forest & $40.17^{\circ},-105.42^{\circ}$ & 2347 & 13.5 & 486 & 126 \\
(5) Eldorado Canyon State Park & $39.92^{\circ},-195.32^{\circ}$ & 2174 & 9.5 & 500 & 118 \\
\hline
\end{tabular}

species and understory production. An increase in understory production could decrease the fire-return interval, as has been shown with cheatgrass in other locations in the western United States (Ziska et al. 2005). The results of this study will be useful to land managers trying to understand the relationship between nonnative species and native species production while planning for future fire scenarios.

\section{Methods}

\section{Study Area}

We selected 5 study sites along the northern Front Range of Colorado in early June 2007. The sites ranged from Poudre Canyon in the north to Golden Gate Canyon in the south (Table 1, Fig. 1). Sampling transects within sites were randomly selected based on the following criteria: all were located on south-facing slopes ranging in elevation from 1840 to $2440 \mathrm{~m}$, in areas that were far enough away from trails, roads, or other developments that they did not show signs of current human disturbance.

The overstory vegetation of the sites consisted predominantly of Pinus ponderosa (ponderosa pine; Fig. 2). Understory vegetation ranged from native forbs and grasses to almost entirely nonnative species. Common grasses included B. inermis, B. tectorum, and Poa nemoralis ssp. interior (inland bluegrass). Common forbs included Heterotheca villosa (hairy false goldenaster), Potentilla ovina (sheep cinquefoil), and Geranium caespitosum (pineywoods geranium). Dwarf shrubs such as Artemisia frigida (prairie sagewort) and Eriogonum umbellatum var. umbellatum (sulphur-flower buckwheat) were common at most sites. Bromus inermis and B. tectorum were the most prevalent nonnative species across the sites, while nonnative forbs such as Lactuca serriola (prickly lettuce) and Tragopogon lamottei (Jack-go-tobed-at-noon) were the most common nonnative forbs.

The complex topography of the Front Range, consisting of varied slopes, elevations, and aspects, means that it is likely that nearby weather stations may not accurately represent precipitation at the sites. Thus, we used PRISM (parameter-elevation regressions on independent slopes model; PRISM Climate Group 2009), a knowledge-based interpolation program that generates continuous climate surfaces based on weather station data and topographic variables (Daly et al. 1994). PRISM interpolates monthly precipitation and temperature data based on nearby weather stations onto $2 \times 2$ $\mathrm{km}^{2}$ grid cells. Using PRISM, the 2007 average precipitation was $496 \mathrm{~mm}$ across all sites, with a range of 460-552 $\mathrm{mm}$ between the northernmost and southernmost sites. Precipitation during the study (June-August) averaged $127 \mathrm{~mm}$ across the sites, with a range of 104-145 mm (Table 1). The average annual temperature across the sites was $7.3^{\circ} \mathrm{C}$.

\section{Sampling}

We sampled 3 transects at each of the 5 study sites. We selected a starting point for the first transect by randomly locating a south-facing slope that contained both nonnative and native species, had no evidence of a recent burn, and had less than a $15 \%$ slope. Using this starting point, we set up 3 parallel 50 -m transects spaced $10 \mathrm{~m}$ apart. Transects were always perpendicular to the slope. We walked each transect and selected 10 plots that represented a gradient from low to high biomass of nonnative species. Where the transect intersected shrubs, trees, or boulders, that area was excluded.

We sampled aboveground biomass in $0.25-\mathrm{m}^{2}$ circular quadrats. Our sampling included green 


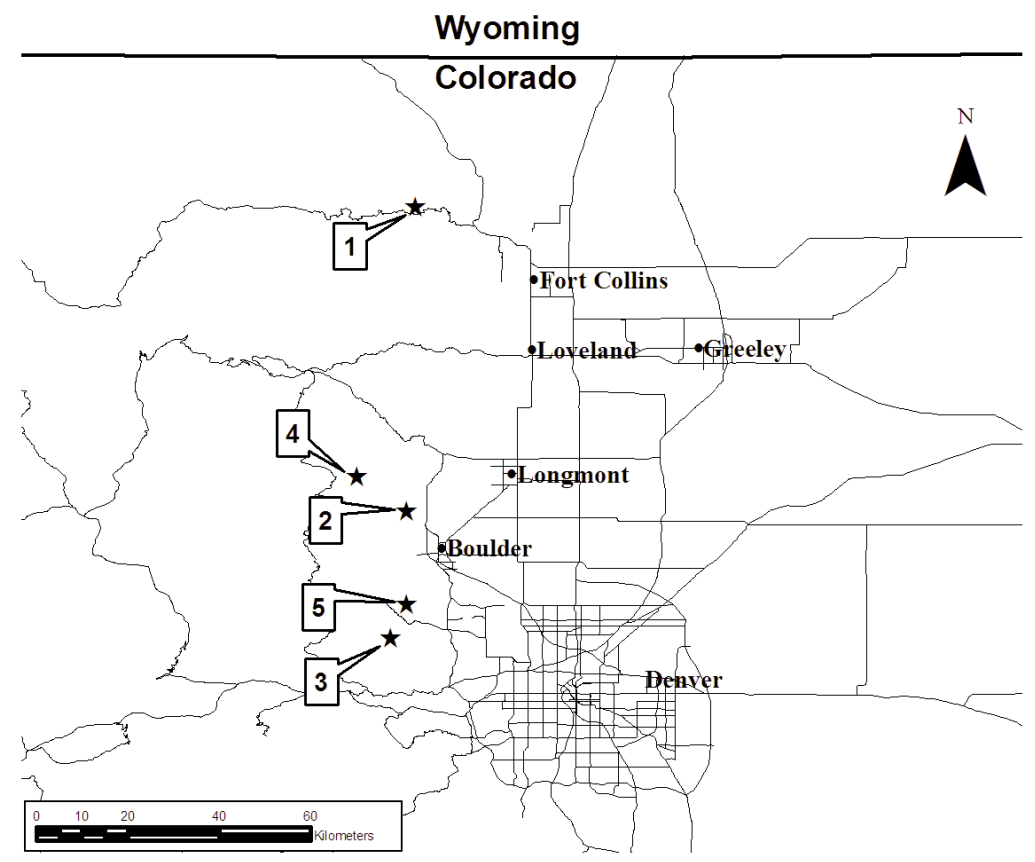

Fig. 1. Map of the 5 ponderosa pine woodland study sites in the Front Range of Colorado.

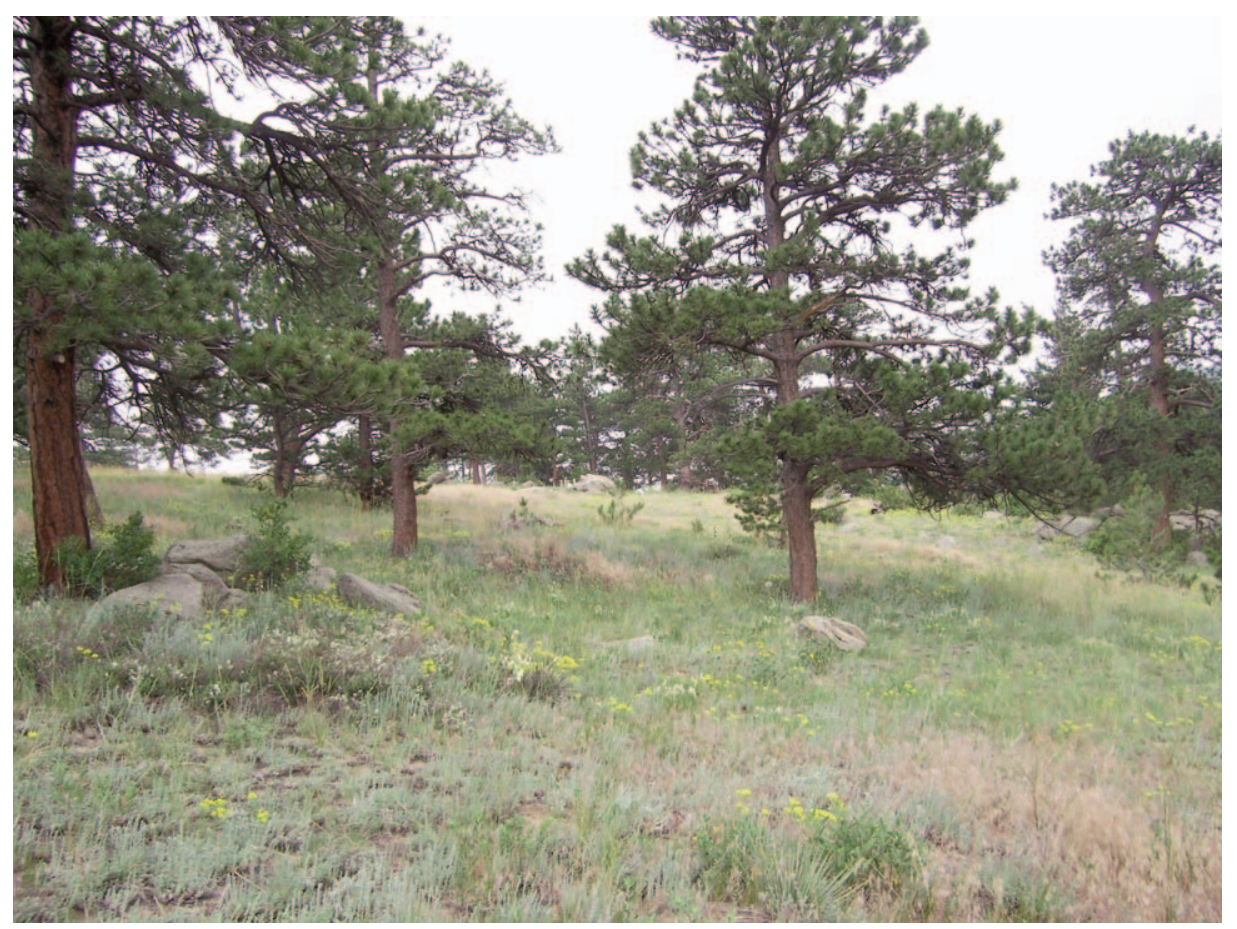

Fig. 2. Ponderosa pine woodland in Golden Gate Canyon State Park, Colorado. Visible in the understory is the nonnative species Bromus tectorum, native grass Hesperostipa comata, and dwarf-shrubs Artemisia frigida and Eriogonum umbellatum var. umbellatum. 


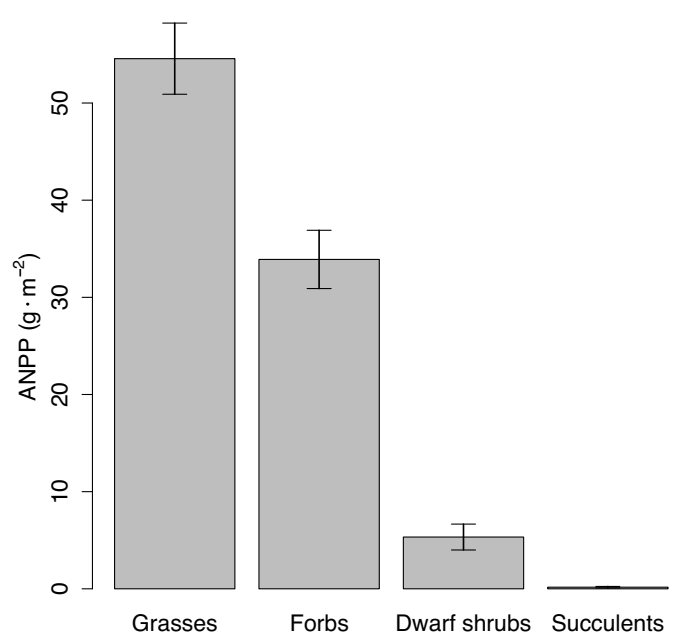

Fig. 3. ANPP and standard error (whisker bars) for each functional group for 5 ponderosa pine woodland study sites in the Front Range of Colorado.

material and recent dead material of grasses and forbs and the current year's green production (excluding woody tissue) for dwarf shrubs. Biomass was clipped at the soil surface, separated by species, and placed in paper bags to dry. We used our biomass data to estimate ANPP (Lauenroth et al. 1986, 2006). Samples were dried for at least 48 hours at $55^{\circ} \mathrm{C}$ and then weighed. We used the USDA-NRCS (2009) PLANTS Database as our naming authority as well as for native and nonnative status.

\section{Statistical Analysis}

We conducted all statistical analyses in $\mathrm{R}$ 2.8.1 (R Development Core Team 2008) and evaluated all tests at $\alpha=0.05$ unless otherwise noted. We investigated differences across sites with an analysis of variance. We used linear random intercept models to perform comparisons between total species richness and total species production, nonnative and native species richness and total species production, native and nonnative species richness, and native and nonnative species production (production was natural-log transformed, as necessary). In these comparisons we utilized site as the random effect to account for the sampling variability of location. We calculated a measure of explained variability, $r^{2}$, for each model, as described by $\mathrm{Xu}$ (2003).

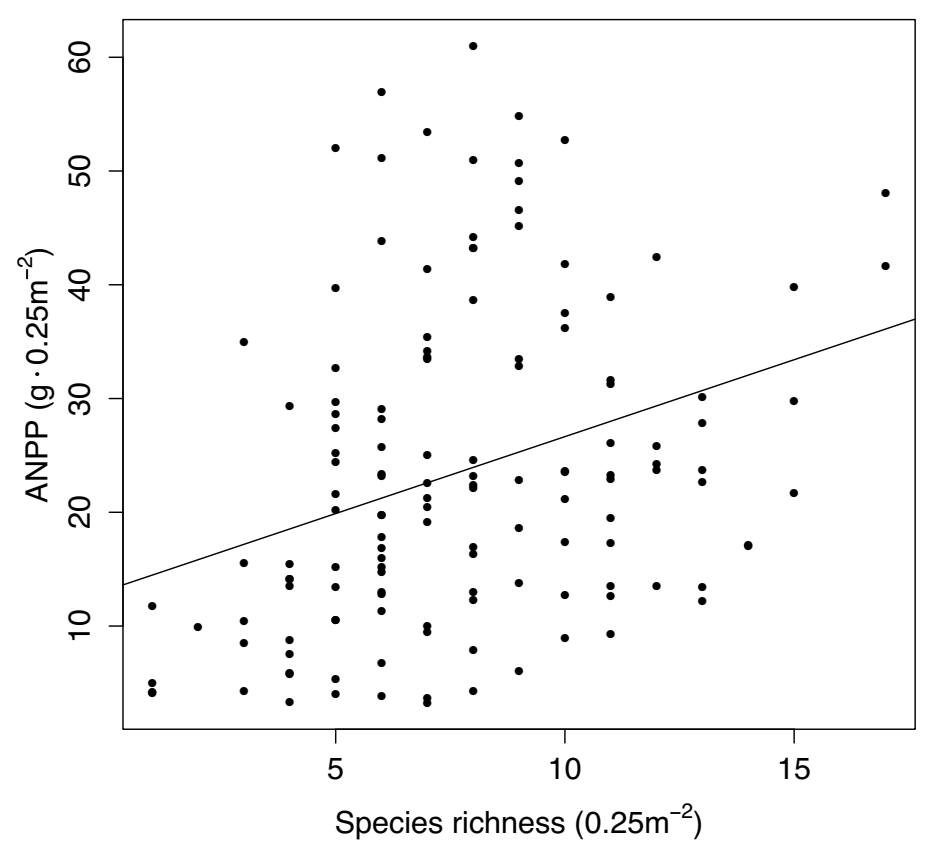

Fig. 4. ANPP as a function of species richness $\left(y=13.13+1.35 x, r^{2}=0.09, P<0.001\right)$ for 5 ponderosa pine woodland study sites in the Front Range of Colorado. 


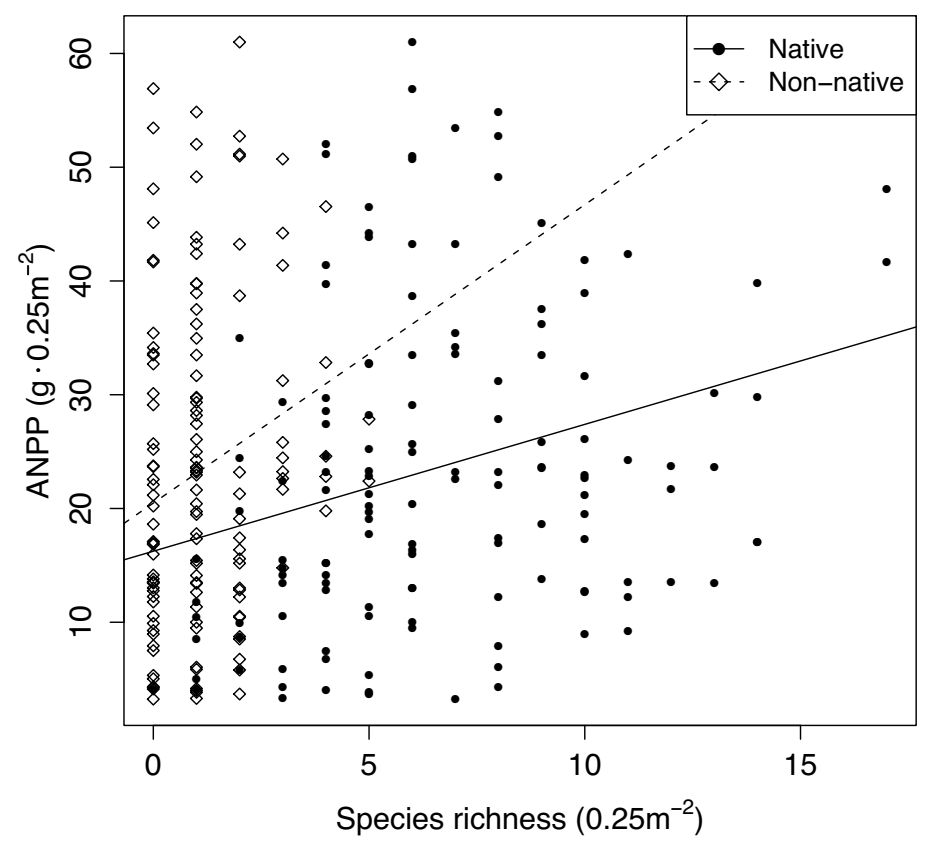

Fig. 5. Total ANPP as a function of species richness for native $\left(y=16.24+1.12 x, r^{2}=0.04, P=0.002\right)$ and nonnative species $\left(y=20.48+2.62 x, r^{2}=0.06, P=0.01\right)$ for 5 ponderosa pine woodland study sites in the Front Range of Colorado.

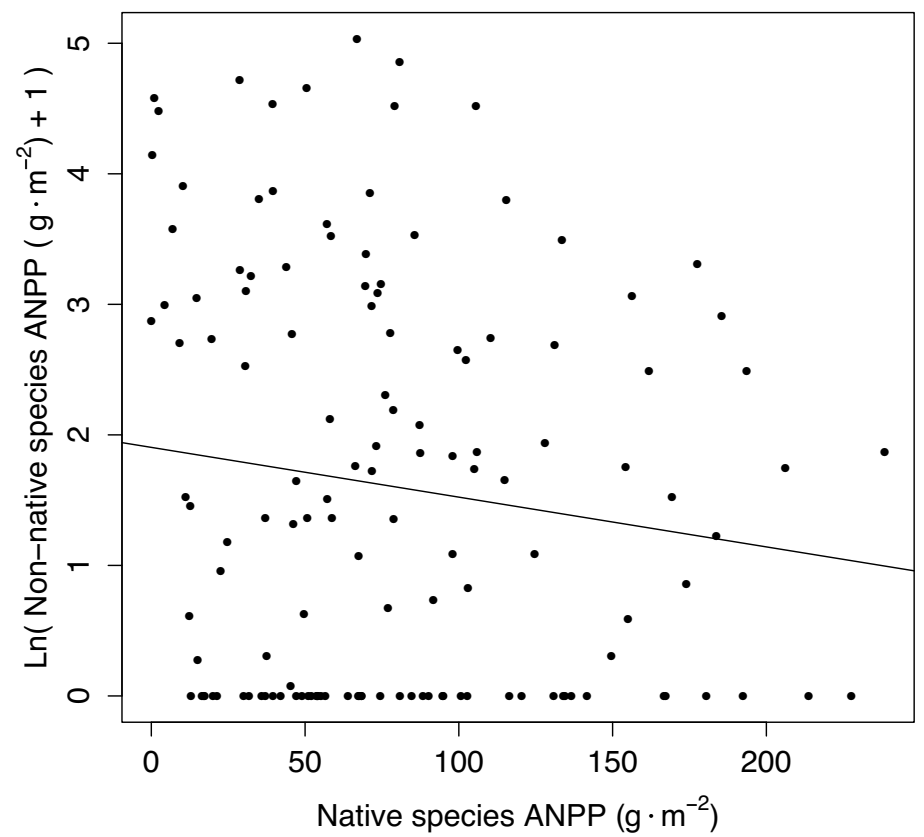

Fig. 6. Transformed nonnative species ANPP as a function of native species ANPP $\left(y=1.90-0.004 x, r^{2}=0.01, P=\right.$ 0.06) for 5 ponderosa pine woodland study sites in the Front Range of Colorado. 
TABLE 2. Total species richness and species richness of native and nonnative species for each site and each quadrat. Richness per site is based on thirty $0.25-\mathrm{m}^{2}$ quadrats for a total of $7.5 \mathrm{~m}^{2}$ sampled per site, and species richness per quadrat is per $0.25 \mathrm{~m}^{2}$. Average plot species richness is shown with standard deviation values in parentheses.

\begin{tabular}{lcrrrr}
\hline \multirow{2}{*}{ Variable } & \multicolumn{5}{c}{ Site number } \\
\cline { 2 - 6 } & \multicolumn{1}{c}{1} & 2 & 3 & 4 & 5 \\
\hline Native species richness per site & 32 & 24 & 42 & 31 & 26 \\
Nonnative species richness per site & 8 & 9 & 1 & 6 & 5 \\
Native species richness per quadrat & $6.7(3.3)$ & $3.4(2.0)$ & $9.7(3.6)$ & $6.5(2.5)$ & $6.3(2.5)$ \\
Nonnative species richness per quadrat & $1.4(1.1)$ & $2.0(1.3)$ & $0.4(0.5)$ & $0.9(1.0)$ & $1.2(1.2)$ \\
\hline
\end{tabular}

\section{RESUlts}

Species Richness and Production

Across all sites, grasses accounted for an average of $58 \%$ of ANPP, forbs accounted for $36 \%$, and dwarf shrubs and succulents accounted for the remaining $6 \%$ (Fig. 3). Average total ANPP was significantly different among sites $(P<0.001$; data not shown). Total ANPP was positively and significantly related to total species richness, although the proportion of the variability in ANPP explained by species richness was low $\left(r^{2}=0.09\right.$; Fig. 4$)$. In particular, total ANPP increased significantly with increasing nonnative species richness (Fig. 5). In contrast to the positive relationships between species richness and production, we found a weak significant negative relationship between native and nonnative species ANPP $(\alpha=0.10$; Fig. 6).

Native and Nonnative Species Richness

Native species richness on a site basis ranged from 24 to 42 , and on a quadrat basis it ranged from 3.4 to 9.7 (Table 2 ). Nonnative richness for sites ranged from 1 to 9 and for quadrats from 0.4 to 2 . We estimate that the understory of the average ponderosa pine woodland site in the Front Range contains 31 native and 6 nonnative species. The average woodland quadrat contains 6.5 native species and 1 nonnative species.

\section{Discussion}

Although there has been controversy surrounding the relationship between species richness and productivity during the past 2 decades (Hooper et al. 2005, Thompson et al. 2005, Hector et al. 2007), evidence for a positive relationship is accumulating for both manipulated and natural plant communities (Marquard et al. 2009). However, we did not find a strong increase in ANPP in species-rich plots in the understory of ponderosa pine woodlands in the Front Range of Colorado. Although the relationship between productivity and species richness was positive in our study, the proportion of the variability in production explained by the number of species in a plot was low $\left(r^{2}\right.$ $=0.09$ ).

While species-rich communities often have higher production, it has also been shown that species-poor communities dominated by nonnative plants can have higher production than similar native plant communities with higher richness (Rout and Callaway 2009). This is contrary to the species richness-productivity relationships common in the literature. We found a positive relationship between nonnative species and production in our study. This is similar to many other past studies (Ehrenfeld 2003, Chengzhang et al. 2008); however, the number of nonnative species explained only a small proportion of the variability in production $\left(r^{2}=\right.$ $0.06)$. For both the case of total species richness and the case of nonnative species richness versus production, additional variables such as site history and soil properties likely affected the results. Additionally, we recognize that aboveground production represents only a portion of total biomass production in grasslands. Had we included belowground production in our total estimate of biomass production, our results may have been different. Future research should include additional explanatory variables that could potentially affect biomass, and it should measure both aboveground and belowground production.

In contrast to the positive relationship between species richness and production, we found a negative relationship between native and nonnative species production. Many past studies have done pairwise comparisons of biomass (one native and one nonnative species, or comparing only invaded to noninvaded sites). 
For example, Daehler (2003) reviewed the published literature on comparisons of a variety of native and nonnative plant characteristics and found the majority of biomass comparisons were done in communities with only one native and one nonnative species. Drenovsky and Batten (2007) compared highly invaded annual grasslands in California to adjacent serpentine grassland with primarily native cover, and they found that the invaded plots had significantly higher biomass than the native plots at the end of the growing season. However, few studies have looked at a range of sites from low to high invasion and determined how this may have affected production. This type of comparison is much more useful in plant communities with diverse species assemblages (Wilsey and Polley 2006), such as ponderosa pine woodlands. Our study covered a range of species assemblages, from low to high nonnative species abundances and including 3 plant functional groups (grasses, forbs, and dwarf shrubs). The understory community was diverse and not subject to experimental manipulations like in many other studies. The relationship we found between nonnative and native species production was significant across sites, yet native species production only explained a small portion of the variability in nonnative species production $\left(r^{2}=0.01\right)$. We suggest that further research should be done in diverse plant communities to test this finding.

Many studies have examined the relationship between native and nonnative species richness (Fridley et al. 2007). At small spatial scales, there tends to be a negative relationship between native and nonnative species richness, although the relationship may be weak (Fridley et al. 2007). We found no significant relationship between native and nonnative species richness in our study. This result was not surprising. Previous work has shown that environmental and historical disturbance factors may alter the apparent relationship between native and nonnative species richness (Renne et al. 2003). Considering the long history of human disturbance in the Front Range, a simple univariate response may not explain the relationship between native and nonnative species richness.

Our study provided some insight into the complex nature of species invasions in a diverse plant community in North America. Clearly the relationships between species invasion and production, and native and nonnative species richness are not simple relationships. This study should serve as a starting point for future research, in which a variety of possible explanatory variables such as disturbance history, proximity to development, and other environmental factors are included in the analysis. Exurban development along the Front Range will likely continue into the future, and understanding the structure and dynamics of understory biomass will be important for fire management. A better understanding of the relationship between nonnative species and production will be useful to land managers in preparing for future climatic and fire regimes in ponderosa pine woodlands.

\section{ACKNOWLEDGMENTS}

We thank NSF-IGERT (Grant DGE-\#022 1595, administered by the PRIMES program at Colorado State University) and McIntire-Stennis (Grant \#1-55253) for supporting this study, the Colorado Department of Natural Resources (Colorado State Parks) for assisting in site selection, Adam Walters for his help in the field, and Aaron Berdanier and Kristen Kaczynski for their assistance with data preparation.

\section{Literature Cited}

Allen, C.D., M. Savage, D.A. Falk, K.F. Suckling, T.W. Swetnam, T. Schulke, P.B. Stacey, et aL. 2002. Ecological restoration of southwestern ponderosa pine ecosystems: a broad perspective. Ecological Applications 12:1418-1433.

Chengzhang, L., P. RonghaO, L. Yiqi, Z. Xuhui, W. Xiaowen, F. Changming, C. Jiakuan, et al. 2008. Altered ecosystem carbon and nitrogen cycles by plant invasion: a meta-analysis. New Phytologist 177: 706-714.

Covington, W.W., And M.M. Moore. 1994. Southwestern ponderosa forest structure: changes since Euro-American settlement. Journal of Forestry 92:39-47.

DAehler, C.C. 2003. Performance comparisons of co-occurring native and alien invasive plants: implications for conservation and restoration. Annual Review of Ecology, Evolution, and Systematics 34:183-211.

Daly, C., R.P. NeIlson, AND D.L. Phillips. 1994. A statistical-topographic model for mapping climatological precipitation over mountainous terrain. Journal of Applied Meteorology 33:140-158.

Drenovsky, R., AND K. BATTEN. 2007. Invasion by Aegilops triuncialis (barb goatgrass) slows carbon and nutrient cycling in a serpentine grassland. Biological Invasions 9:107-116.

EHrEnFELD, J.G. 2003. Effects of exotic plant invasions on soil nutrient cycling processes. Ecosystems 6:503523.

Fridley, J.D., J.J. Stachowicz, S. Naeem, D.F. SaX, E.W. Seabloom, M.D. Smith, T.J. Stohlgren, D. Tilman, 
AND B. VON Holle. 2007. The invasion paradox: reconciling pattern and process in species invasions. Ecology 88:3-17.

Hector, A., J. Joshi, M. Scherer-Lorenzen, B. Schmid, E.M. SPehn, L. Wacker, M. Weilendann, E. BazeLeY-White, C. Beierkuhnlein, M.C. Caldeira. 2007. Biodiversity and ecosystem functioning: reconciling the results of experimental and observational studies. Functional Ecology 21:998-1002.

Hooper, D.U., F.S. Chapin III, J.J. Ewel, A. Hector, P. Inchausti, S. Lavorel, J.H. LaWton, D.M. Lodge, M. Loreau, S. NAEEM, ET AL. 2005. Effects of biodiversity on ecosystem functioning: a consensus of current knowledge. Ecological Monographs 75:3-35.

Lauenroth, W.K., H.W. HunT, D.M. SwifT, aND J.S. Singh. 1986. Estimating aboveground net primary production in grasslands: a simulation approach. Ecological Modelling 33:297-314.

Lauenroth, W., A. Wade, M. Williamson, B. Ross, S. Kumar, and D. Cariveau. 2006. Uncertainty in calculations of net primary production for grasslands. Ecosystems 9:843-851.

Mack, R.N., D. Simberloff, W.M. Lonsdale, H. Evans, M. Clout, AND F.A. BAZZAZ. 2000. Biotic invasions: causes, epidemiology, global consequences, and control. Ecological Applications 10:689-710.

Marquard, E., A. Weigelt, C. Roscher, M. Gubsch, A. Lipowsky, AND B. SCHMID. 2009. Positive biodiversity-productivity relationship due to increased plant density. Journal of Ecology 97:696-704.

PRISM Climate Group. 2009. Prism Climate Group [home page]. Oregon State University, Corvallis, OR. Available from: http://www.prismclimate.org

R Development Core Team. 2008. R: a language and environment for statistical computing. Reference index version 2.8.1. $\mathrm{R}$ Foundation for Statistical Computing, Vienna, Austria. Available from: http:// www.r-project.org

Renne, I.J., B.F. Tracy, and M. Rejmanek. 2003. The rich get richer: responses. Frontiers in Ecology and the Environment 1:122-123.
Rout, M.E., and R.M. Callaway. 2009. An invasive plant paradox. Science 324:734-735.

Swetnam, T.W., C.D. Allen, and J.L. Betancourt. 1999 Applied historical ecology: using the past to manage for the future. Ecological Applications 9:1189-1206.

Thompson, K., A.P. Askew, J.P. GRIME, N.P. DunNETT, AND A.J. WILLIS. 2005. Biodiversity, ecosystem function and plant traits in mature and immature plant communities. Functional Ecology 19:355-358.

USDA-NRCS. 2009. The PLANTS Database [online]. National Plant Data Center, Baton Rouge, LA. Available from: http://plants.usda.gov

Veblen, T.T., T. Kitzberger, and J. Donnegan. 2000. Climatic and human influences on fire regimes in ponderosa pine forests in the Colorado Front Range. Ecological Applications 10:1178-1195.

Vitousek, P.M., C.M. D’Antonio, L.L. Loope, M. RejMANEK, AND R. WESTBROOKS. 1997. Introduced species: a significant component of human-caused global change. New Zealand Journal of Ecology 21:1-16.

Wilcove, D.S., D. Rothstein, D. Jason, A. Phillips, and E. Losos. 1998. Quantifying threats to imperiled species in the United States. BioScience 48:607-615.

Wilsey, B., AND H.W. Polley. 2006. Aboveground productivity and root-shoot allocation differ between native and introduced grass species. Oecologia 150: 300-309.

$\mathrm{XU}$, R. 2003. Measuring explained variation in linear mixed effects models. Statistics in Medicine 22:3527-3541.

Ziska, L.H., J.B. ReEves, AND I.I.I.B. Blank. 2005. The impact of recent increases in atmospheric $\mathrm{CO}_{2}$ on biomass production and vegetative retention of cheatgrass (Bromus tectorum): implications for fire disturbance. Global Change Biology 11:1325-1332.

Received 27 August 2009 Accepted 18 February 2010 